\title{
DOE/PC/89772-T/2
}

\section{APPLICATIONS OF MICELLAR ENZYMOLOGY TO CLEAN COAL}

\section{TECHNOLOGY}

$\mathrm{DOE} / \mathrm{PC} / 89772--\mathrm{TI} 2$

\author{
Tenth Quarterly Report
}

DE92 016632

\author{
DOE Grant No. DE-FG22-89PC89772
}

\author{
Submitted to: \\ U.S. Department of Energy \\ Pittsburgh Energy Technology Center \\ P.O. Box 10940 \\ Pittsburgh, PA 15236
}

\author{
Prepared by: \\ Carol T. Walsh, Ph.D. \\ Principal Investigator \\ Boston University School of Medicine \\ 80 E. Concord Street, L-603 \\ Boston, MA 02118 \\ 617-638-4326
}

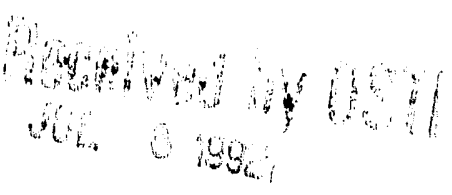

April 29, 1992

US/DOE Patent Clearance is not required prior to the publication of this document.

\section{DISCLAIMER}

\begin{abstract}
This report was prepared as an account of work sponsored by an agency of the United States Government. Neither the United States Government nor any agency thereof, nor any of their employees, makes any warranty, express or implied, or assumes any legal liability or responsibility for the accuracy, completeness, or usefulness of any information, apparatus, product, or process disclosed, or represents that its use would not infringe privately owned rights. Reference herein to any specific commercial product, process, or service by trade name, trademark, manufacturer, or otherwise does not necessarily constitute or imply its endorsement, recommendation, or favoring by the United States Government or any agency thereof. The views and opinions of authors expressed herein do not necessarily state or reffect those of the Unitod States Government or any agency thereof.
\end{abstract}




\section{TABLE OF CONTENTS}

Section

Page

1

INTRODUCTION

1

1.1

Program Overview

1

1.2 Surnmary of Results 2

2

MATERIALS AND METHODS

2

2.1

Materials

2

2.2

Methods

3

2.2.1 Enzyme Activity in Reverse Micelle Solution with EPS as Substrate

3

2.2.2a Quantitation of EPS Sulfur Oxidation Products 3

2.2.2b Reverse Micelle Solutions 4

3 RESULTS 5

3.1 EPS Sulfoxidation by Chloroperoxidase in 5 AOT/Isooctane Reverse Micelle Solutions

3.2 EPSx Sulfoxidation by Chloroperoxidase in AOT/Isooctane Reverse Micelle Solutions

3.3 Secondary Structure of Chloroperoxidase in Aqueous and Reverse Micelle Solutions 


\section{LIST OF FIGURES}

Figure

Figure 1: $\quad \mathrm{H}_{2} \mathrm{O}_{2}$ Dependence of EPS Sulfoxidation by

Chloroperoxidase in Reverse Micelle Solution

Figure 2: $\quad$ Effect of Method of $\mathrm{H}_{2} \mathrm{O}_{2}$ Addition on EPS Sulfoxidation by

7 Chloroperoxidase in Reverse Micelle Solution

Figure 3: $\quad$ Effect of Sequential $\mathrm{H}_{2} \mathrm{O}_{2}$ Addition on EPS Sulfoxidation by 8 Chloroperoxidase in Reverse Micelle Solution

Figure 4: $\quad$ Effect of Time of Sequential $\mathrm{H}_{2} \mathrm{O}_{2}$ Addition on EPS

Sulfoxidation by Chloroperoxidase in Reverse Micelle Solution

Figure 5: $\quad$ Effect of $\mathrm{H}_{2} \mathrm{O}_{2}$ Concentration Added Directly to

Chloroperoxidase-containing Reverse Micelle Solution on EPS Sulfoxidation

Figure 6: Relationship of Initial $\mathrm{H}_{2} \mathrm{O}_{2}$ Concentration to EPS Sulfoxidation by Chloroperoxidase in Reverse Micelle Solution

Figure 7: Comparison of EPS Sulfoxidation by Choroperoxidase in Aqueous and Reverse Micelle Solutions

Figure 8: Effect of Sequential Addition of Enzyme and $\mathrm{H}_{2} \mathrm{O}_{2}$ on Oxidation of EPS and EPSx in AOT/isooctane Reverse Micelle Solutions

Figure 9: Effect of Sequential Addition of Enzyme and $\mathrm{H}_{2} \mathrm{O}_{2}$ on Oxidation of EIS to an Unidentified Metabolite in AOT/isooctane Reverse Micelle Solutions

Figure 10: EPSx Oxidation by Choroperoxidase in Reverse Micelle Solution

Figure 11: CD Spectra of Chloroperoxidase in Aqueous (top) and Reverse Micelle (bottom) Solutions

Figure12: Superimposed CD Spectra of Chloroperoxidase in Aqueous and Reverse Micelle Solutions 


\section{Section 1}

\section{INTRODUCTION}

\subsection{Program Overview}

Full implementation of coal fuel sources will require more effective methods of providing "clean coal" as a fuel source. Methods must be developed to reduce the sulfur content of coal which significantly contributes to environmental pollution. This project is designed to develop methods for pre-combustion coal remediation by implementing recent advances in enzyme biochemistry. The novel approach of this study is incorporation of hydrophilic oxidative enzymes in reverse micelles in an organic solvent. Enzymes from commercial sources or microbial extracts are being investigated for their capacity to remove organic sulfur from coal by oxidation of the sulfur groups, splitting of C-S bonds and loss of sulfur as sulfuric acid.

Dibenzothiophene (DBT) and ethylphenylsulfide (EPS) are serving as models of organic sulfur-containing components of coal in initial studies.

A goal of this project is to define a reverse micelle system that optimizes the catalytic activity of enzymes toward desulfurization of model compounds and ultimately coal samples. Among the variables which will be examined are the surfactant, the solvent, the water:surfactant ratic and the $\mathrm{pH}$ and ionic strength of the aqueous phase. Studies by several groups (Martinek et al., 1981; Kabanov et al., 1988; Martinek, 1989; Verhaert et al., 1990) have shown that the surfactant AOT over a broad concentration range in organic solvents produces micelles, comparatively uniform in diameter, which incorporate hydrophilic enzymes. The activity (kcat) of certain enzymes in this system is higher than in aqueous solution. This surfactant is therefore being examined first, although the potential disadvantages of an $\mathrm{SO}_{3}$ containing molecule have 
been recognized. Other surfactants to be tested include Tritons, Tweens, CTAB and Brij 35.

\subsection{Summary of Results}

Definitive and substantial chloroperoxidase-mediated sulfoxidation of EPS in an AOT/isooctane reverse micelle solution was demonstrated. Nearly complete conversion of EPS to EPSx could be achieved by direct addition of peroxide in phosphate buffer to enzyme-containing reverse micelle solutions. Under conditions tested, further oxidation to EPSn was not observed, although chloroperoxidase in reverse micelles was shown to catalyze oxidation of EPSx as starting material to both EPSn and an unidentified metabolite. The sequential addition of enzyme and peroxide during the reverse micelle incubation was found to enhance sulfoxidation, but levels of EPSn remained low. Chloroperoxidase serves as an effective catalyst of sulfoxidation in a predominantly organic medium despite considerable modification of secondary structure indicated by circular dichroism studies.

\section{Section 2}

\section{MATERIALS AND METHODS}

\subsection{Materials}

Enzyme studies were performed with chloroperoxidase from Caldariomyces fumago. Chloroperoxidase, $2.7 \mathrm{mg} / \mathrm{ml}$ in $0.1 \mathrm{M}$ sodium phosphate buffer ( $\mathrm{pH} 4.0$ ), was obtained from Sigma Chemical Co. and refrigerated at $0{ }^{\circ} \mathrm{C}$. EPS (Aldrich Chemical Co.) and EPSx (K\&K Laboratories) were evaluated as enzyme substrate. The reverse micelle solutions contained surfactant AOT (0.1 M, di (2-ethylhexyl) sodium sulfosuccinate from Sigma Chemical Co.), organic solvent isooctane (OmniSolv, EM Scientific), and 2.3\% or $4.6 \%(\mathrm{v} / \mathrm{v})$ aqueous phase (potassium phosphate, $0.1 \mathrm{M}, \mathrm{pH} 2.75)$. Hexane, chloroform, acetone and isopropanol, all from Fisher Scientific, were used in 
sample analysis. Solid phase extractions were performed on $20 \mathrm{H}$ (diol) Bond Elut (500 mg) Bond Elut columns from AnalytiChem Inc. (Van Horne, 1990). A Scientific Industries rotator was used for agitation of incubation samples.

\subsection{Methods}

\subsubsection{Enzyme Activity in Reverse Micelle Solution with EPS} as Substrate

\subsection{1a Quantitation of EPS Sulfux Oxidation Products}

Isopropanol (1 column volume, $2.8 \mathrm{ml}$ ) was used to solvate a $20 \mathrm{H}$ (diol) Bond Elut column (500 mg). Excess isopropanol was removed with two column-volume washes of isooctane at a flow rate of $15 \mathrm{ml} / \mathrm{min}$. A $0.5 \mathrm{ml}$ aliquot of standards or experimental samples in reverse micelle solutions was applied and run to dryness at a flow rate of $4.8 \mathrm{ml} / \mathrm{min}$. The sample was eluted five times with $0.25 \mathrm{ml}$ aliquots of $80: 20$ chloroform:acetone. Eluates 2-5 were collected, solvent evaporated under $\mathrm{N}_{2}$, and the residue redissolved in 85:15 hexane:isopropanol $(0.1 \mathrm{ml})$ for HPLC analysis. Recovery of $0.009 \mathrm{mM}$ or 0.125 mM EPSx from reverse micelle solution, based on comparison of area values to that of EPSx in hexane:isopropanol (85:15), consistently averaged about $100 \%$ for solutions with $2.3 \%$ aqueous phase and $50 \%$ for solutions with $4.6 \%$ aqueous phase.

EPS (0.5 mM), EPSx (0.009 or $0.125 \mathrm{mM})$, and EPSn $(0.5 \mathrm{mM})$ were added alone to hexane:isopropanol $(85: 15, \mathrm{v} / \mathrm{v})$. These standards and aliquots of eluates from extraction columns $(20 \mu \mathrm{l})$ were analyzed with a Shimadzu HPLC system (LC-600 analytical pumps) using a Waters $\mu$ Porasil column (10 $\mu \mathrm{m}, 3.9 \times 300 \mathrm{~mm})$. This normal phase chromatographic system was based on the method used by Light et al. (1982) and Waxman et al. (1982) to separate sulfones and sulfoxides. The mobile phase consisted of $85: 15$ hexane:isopropanol at a flow rate of $1.2 \mathrm{ml} / \mathrm{min}$ for $15.0 \mathrm{~min}$. The detector was a SPD- 
6AV UV-VIS spectrophotometer set at $254 \mathrm{~nm}$. Chromatograms were produced on a Chromatopac CR 501 data processor.

\subsection{1b Reverse Micelle Solutions}

EPS $(0.5 \mathrm{mM})$ or EPSx $(0.5 \mathrm{mM})$ was incubated with chloroperoxidase and $\mathrm{H}_{2} \mathrm{O}_{2}$ for $0.5-1.5 \mathrm{hr}$ at $23^{\circ} \mathrm{C}$ in reverse micelle solutions. Solutions were made by: 1) making separate enzyme-containing and peroxide-containing reverse micelle solutions with EPS and combining them, or 2) making an enzyme-containing reverse micelle solution with EPS and then directly adding peroxide in aqueous buffer. The solutions were vortexed for $1 \mathrm{~min}$ and then incubated. Controls included EPS without enzyme or peroxide and EPS with peroxide and no enzyme. All conditions were tested with at least duplicate incubations; replicate aliquots of each $(0.5 \mathrm{ml})$ were analyzed by $20 \mathrm{H}$ (diol) extraction and HPLC.

\subsubsection{Comparison of Secondary Structure of Chloroperoxidase in Aqueous and Reverse Micelle Solutions}

Aspects of the secondary structure of chloroperoxidase were determined by circular dichroism using an Aviv Model 62 DS CD Spectrophotometer. Solutions of the enzyme in aqueous buffer $(0.2 \mu \mathrm{M}$ in $0.1 \mathrm{mM}$ phosphate buffer, $\mathrm{pH} 2.75$ ) and in reverse micelles ( $100 \mu \mathrm{M}$ in buffer added $2.3 \% \mathrm{v} / \mathrm{v}$ to $0.1 \mathrm{M} \mathrm{AOT} /$ isooctane) were scanned from $190-250 \mathrm{~nm}$ in $1 \mathrm{~mm}$ and $0.2 \mathrm{~mm}$ path-length cells respectively. Scans, five replicates per sample, were corrected for background results from corresponding non-enzyme containing solutions. Millidegree values were then converted to molar ellipticity ( $\varnothing)$, using the enzyme concentration in the aqueous phase, an amino acid molecular weight for the enzyme of 32,974 daltons, and a mean amino acid residue weight of 110 (Fang et al., 1986). This study was conducted in collaboration with Dr. Mary 
Walsh, Assistant Professor of Biophysics at Boston University School of Medicine.

\section{Section 3}

\section{RESULTS}

\subsection{EPS Sulfoxidation by Chloroperoxidase in AOT/Isooctane Reverse Micelle Solutions}

A study (described in the Ninth Report) was replicated, which demonstrated that chloroperoxidase in a reverse micelle solution mediated the sulfoxidation of EPS when $\mathrm{H}_{2} \mathrm{O}_{2}$ was added in its own reverse micelle solution. Only low levels of conversion were achieved with the highest peroxide concentration tested (Figure 1). An equivalent low degree of conversion occurred when the peroxide was added directly to the enzymecontaining reverse micelle solution (Figure 2). Sulfoxidation of EPS to EPSx was markedly enhanced to nearly $90 \%$ conversion, when an additional aliquot of peroxide was added directly to the enzyme-peroxide reverse micelle solutions at $0.5 \mathrm{hr}$ and incubated for another $0.5 \mathrm{hr}$ (Figure 3). This marked increase in enzyme activity was observed as well when the additional peroxide (20 $\mathrm{mM}$ in phosphate buffer) was added immediately after making the reverse micelle solutions (Condition 1, Figure 4, total incubation time of $0.5 \mathrm{hr}$ ) without the initial $0.5 \mathrm{hr}$ incubation (Condition 2, Figure 4, total incubation time of $1.0 \mathrm{hr}$ ). Substantial although lesser conversion was achieved with only direct addition of peroxide; the magnitude of EPSx production was about the same with iwo and four-fold lower concentrations of peroxide (Figure 5). Insignificant levels of EPSx were produced in control solutions without enzyme which contained the highest peroxide concentration tested (Figure 5). A repeat study indicated that direct addition of peroxide $(20 \mathrm{mM}$ in phosphate buffer) to enzyme-containing reverse micelle solutions could achieve about 


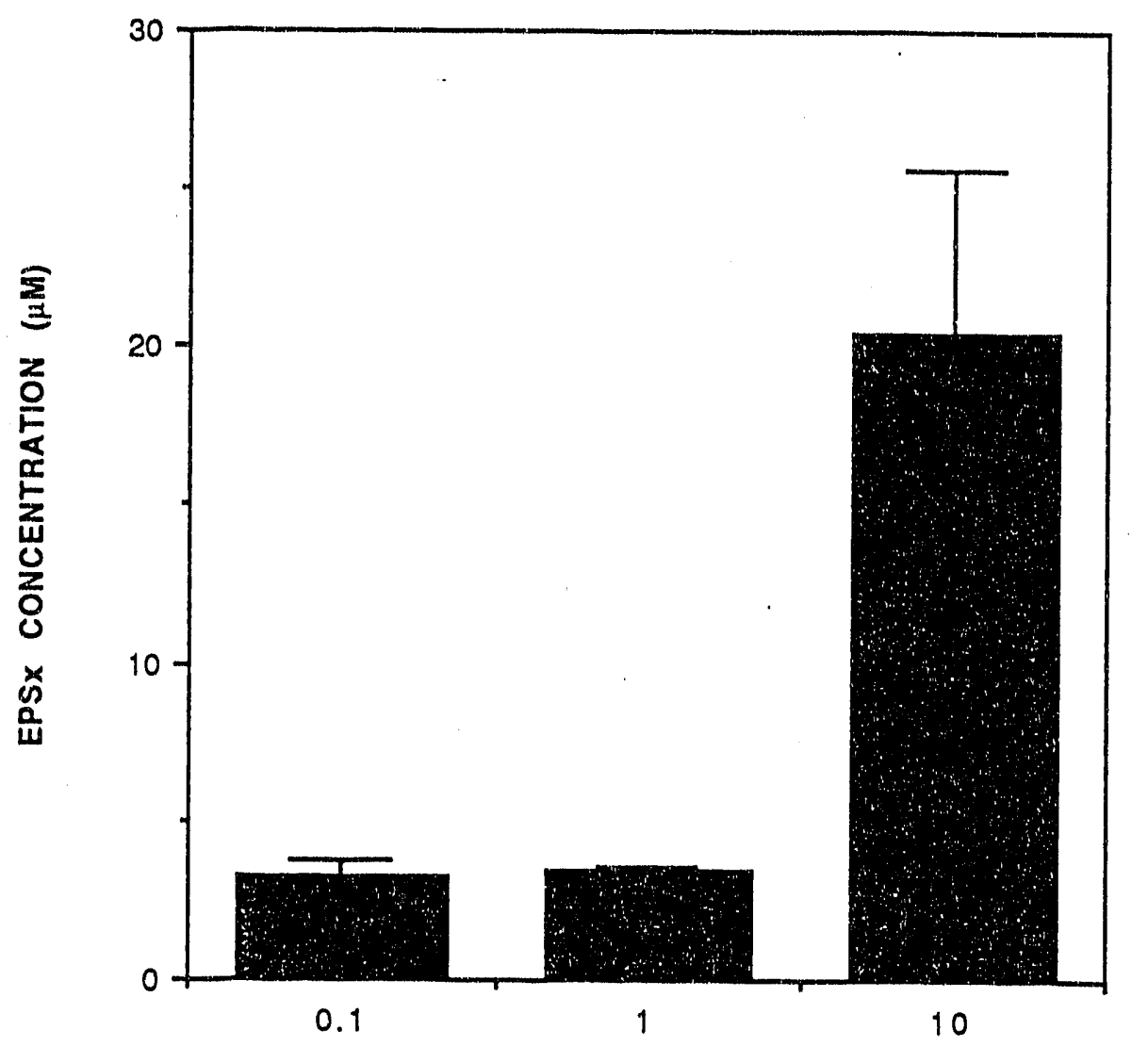

H2O2 CONCENTRATION (mM) IN AQUEOUS PHASE

Fig.1 $\mathrm{H}_{2} \mathrm{O}_{2}$ Depeñdence of EPS Sulfoxidation by Chloroperoxidase in Reverse Micelle Solution. EPS (0.5 mM) was incubated with chloroperoxidase $(1 \mu \mathrm{M}$ in aqueous phase) and $\mathrm{H}_{2} \mathrm{O}_{2}\left(0.1,1.0\right.$, and $10 \mathrm{mM}$ in aqueous phase) for 0.5 hour at $23^{\circ} \mathrm{C}$ in reverse micelle solutions. Solutions were made by making separate enzyme-containing ( $2 \mu \mathrm{M}$ in $2.3 \%$ aqueous phase) and $\mathrm{H}_{2} \mathrm{O}_{2}$ containing $(0.2,2.0$, and $20 \mathrm{mM}$ in aqueous phase) AOT/isooctane solutions and then combining them. All conditions were tested with duplicate incubations; replicate aliquots of each $(0.5 \mathrm{ml})$ were analyzed by $2 \mathrm{OH}$ (diol) extraction and HPLC. Error bars represent standard deviation. 


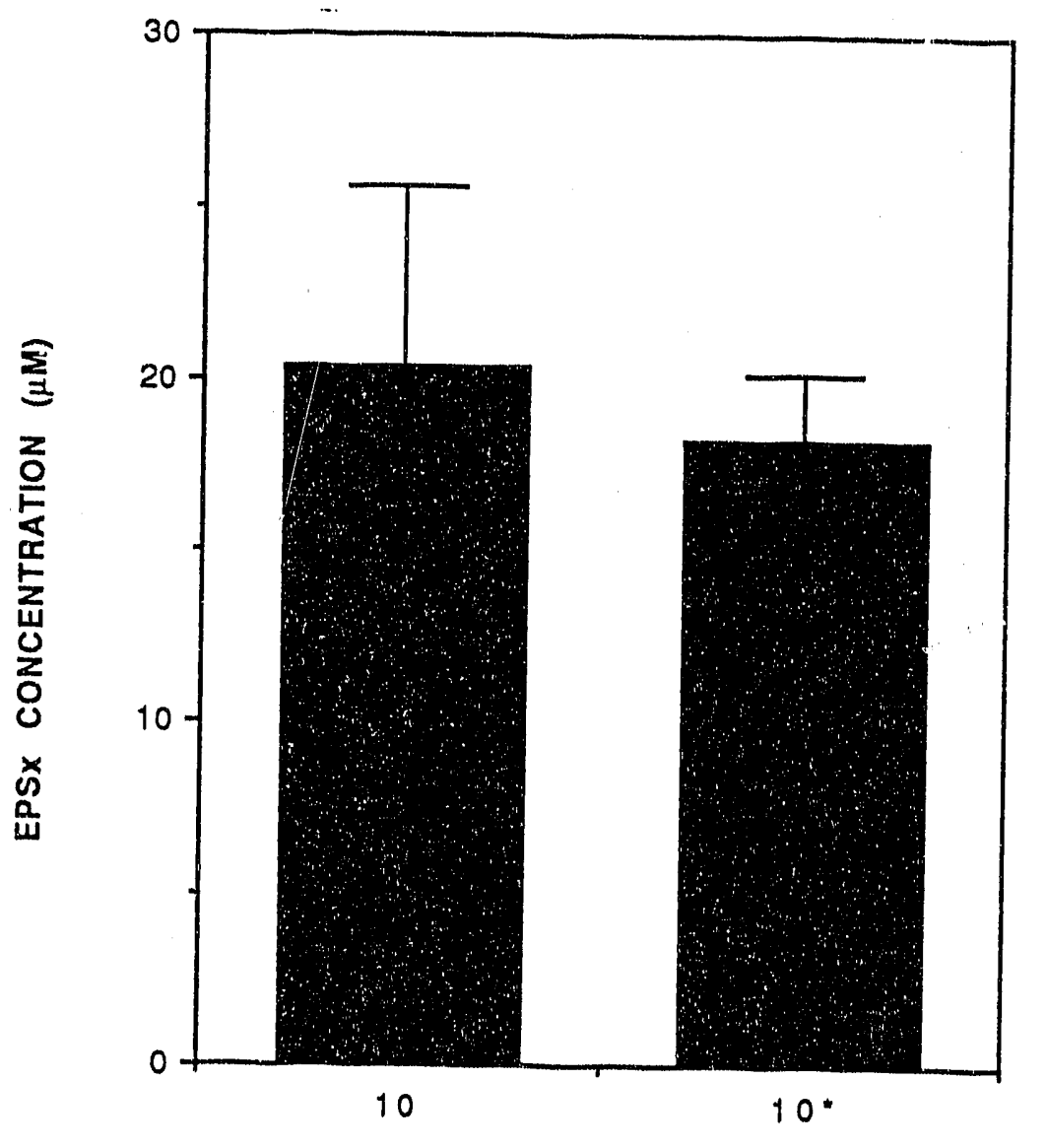

H2O2 CONCENTRATION (mM) IN AQUEOUS PHASE

Fig.2 Effect of Method of $\mathrm{H}_{2} \mathrm{O}_{2}$ Addition on EPS Sulfoxidation by Chloroperoxidase in Reverse Micelle Solution. EPS $(0.5 \mathrm{mM})$ was incubated with chloroperoxidase $(1 \mu \mathrm{M}$ in aqueous phase) and $\mathrm{H}_{2} \mathrm{O}_{2}$ (10 $\mathrm{mM}$ in aqueous phase) for 0.5 hour at $23^{\circ} \mathrm{C}$ in reverse micelle solutions. Solutions were made by 1) combining equal volumes of separate enzyme-containing $(2 \mu \mathrm{M}$ in $2.3 \%$ aqueous phase) and peroxide-containing $(20 \mathrm{mM}$ in $2.3 \%$ aqueous phase) $0.1 \mathrm{M}$ AOT/isooctane solutions; "2) making an enzymecontaining $(2 \mu \mathrm{M}$ in $1.15 \%$ aqueous phase) reverse micelle solution and then directly adding $20 \mathrm{mM} \mathrm{H}_{2} \mathrm{O}_{2}(1.15 \% \mathrm{v} / \mathrm{v})$. All conditions were tested with duplicate incubations; replicate aliquots of each $(0.5 \mathrm{ml})$ were analyzed by $2 \mathrm{OH}$ (diol) extraction and HPLC. Error bars represent standard deviation. 


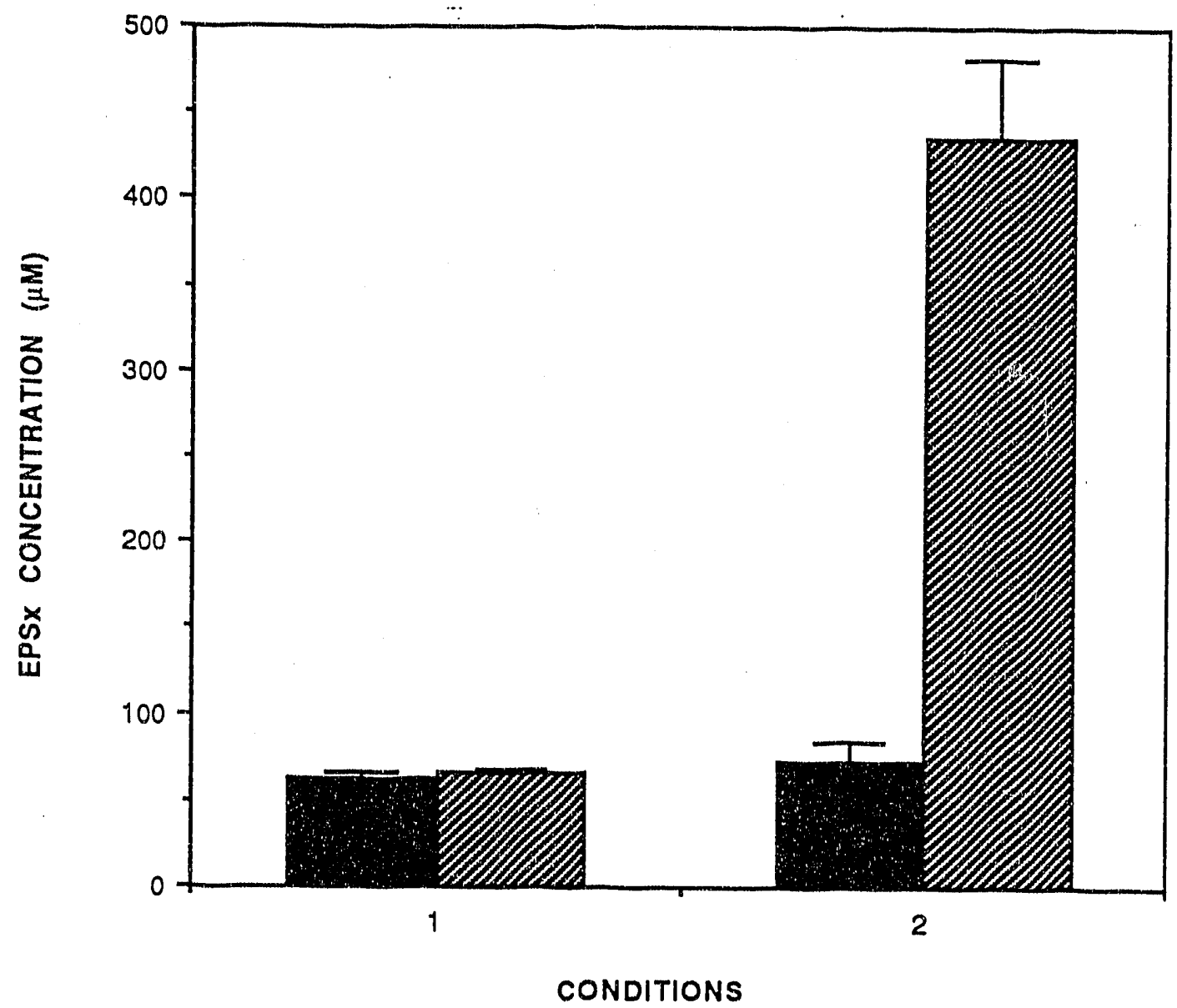

Fig. 3 Effect of Sequential $\mathrm{H}_{2} \mathrm{O}_{2}$ Addition on EPS Sulfoxidation by Chloroperoxidase in Reverse Micelle Solution. Reverse micelle solutions were made by combining separate chloroperoxidase-containing ( $2 \mu \mathrm{M}$ in $2.3 \%$ aqueous phase) and $\mathrm{H}_{2} \mathrm{O}_{2}$-containing ( $20 \mathrm{mM}$ in $2.3 \%$ aqueous phase) $0.1 . \mathrm{M}$ AOT/isooctane solutions. Aliquots of the reverse micelle solutions were removed for EPSx determination after 0.5 hour incubations (dark bars). At that time additional phosphate buffer $(2.3 \%$ of the total volume), either alone (condition 1) or containing $20 \mathrm{mM} \mathrm{H} \mathrm{H}_{2} \mathrm{O}_{2}$ (condition 2), was added and samples incubated for an additional 0.5 hour (hatched bars). All conditions were tested with duplicate incubations; replicate aliquots of each $(0.5 \mathrm{ml})$ were analyzed by $20 \mathrm{H}$ (diol) extraction and HPLC. Error bars represent standard deviation. 


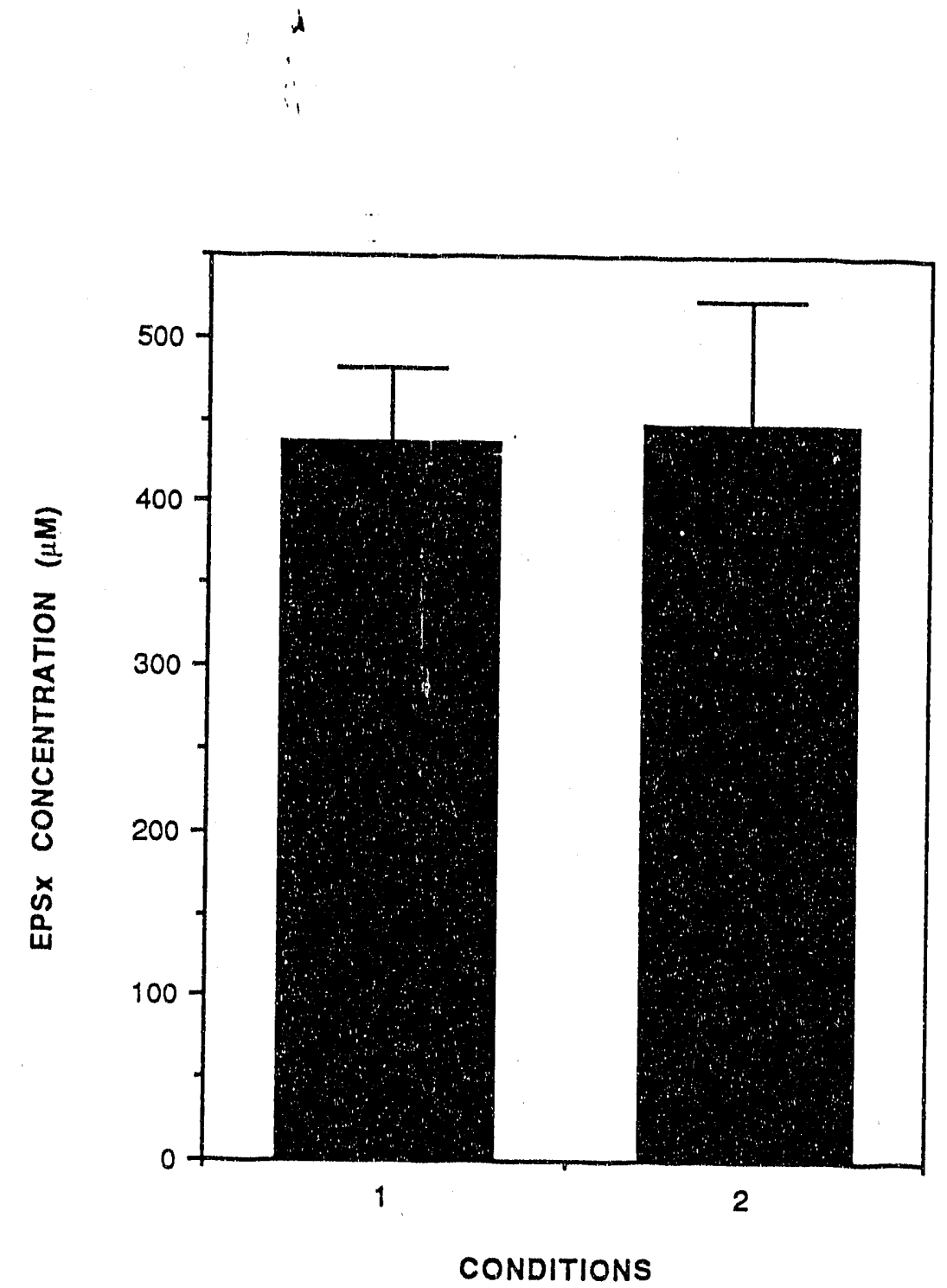

Fig.4 Effect of Time of Sequential $\mathrm{H}_{2} \mathrm{O}_{2}$ Addition on EPS Sulfoxidation by Chloroperoxidase in Reverse Micelle Solution. After combining separate enzyme-containing (2 UM in $2.3 \%$ aqueous phase) and $\mathrm{H}_{2} \mathrm{O}_{2}$-containing $(20 \mathrm{mM}$ in $2.3 \%$ aqueous phase) reverse micelle solutions, $20 \mathrm{mM} \mathrm{H}_{2} \mathrm{O}_{2}$ ( $2.3 \%$ of total volume) was directly added, immediately (condition 1) or after a $0.5 \mathrm{hr}$ incubation (condition 2). Aliquots were removed for EPSx analysis $0.5 \mathrm{hr}$ after the second direct addition of $\mathrm{H}_{2} \mathrm{O}_{2}$. All conditions were tested with duplicate incubations. Error bars represent standard deviation. 


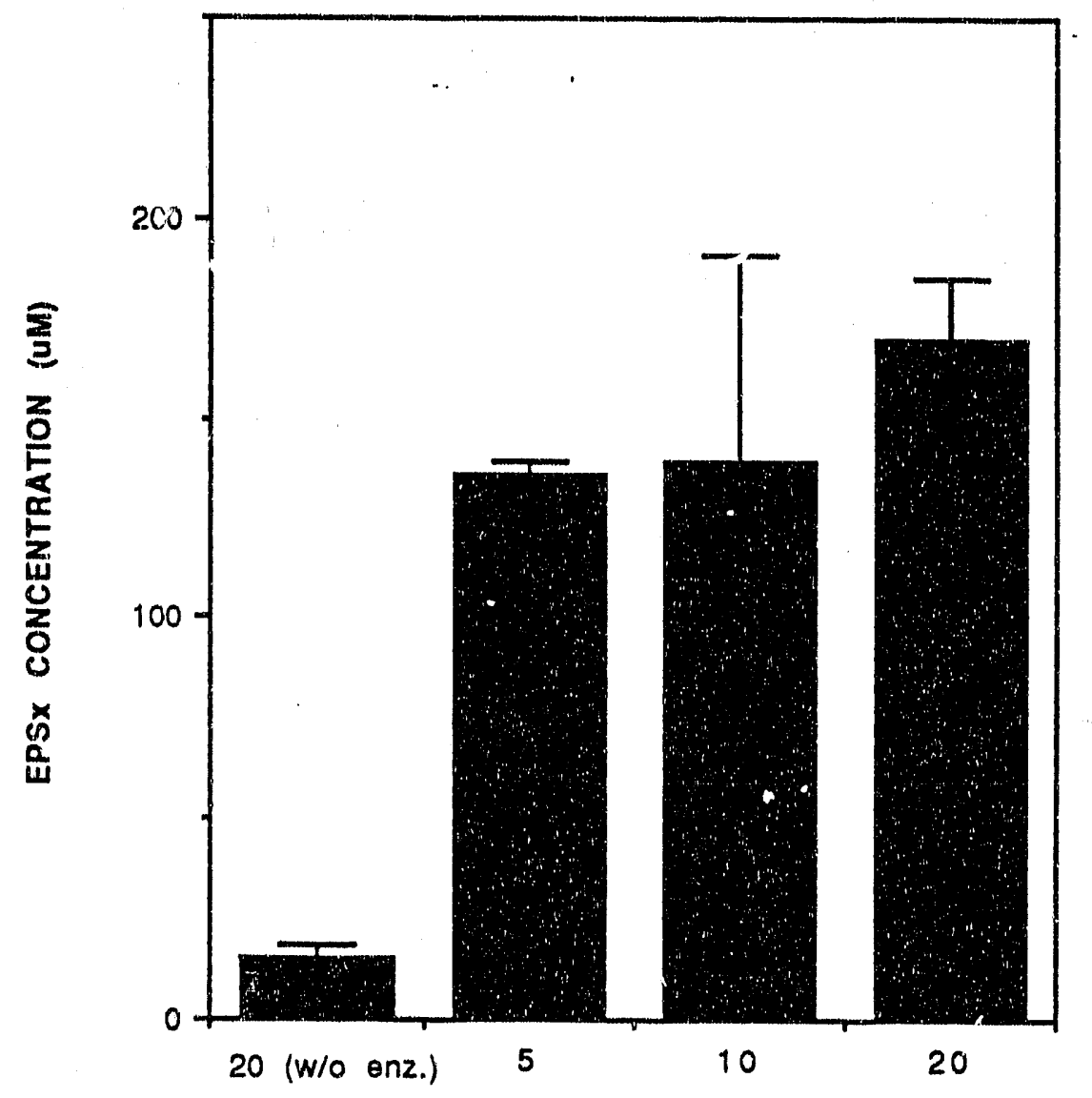

H2O2 CONCENTRATION (mM) IN AQUEOUS PHASE

Fig. 5: Effect of $\mathrm{H}_{2} \mathrm{O}_{2}$ Concentration Added Directly to Chloroperoxidasecontaining Reverse Micelle Solution on EPS Sulfoxidation. $\mathrm{H}_{2} \mathrm{O}_{2}$ ( $10-$ $40 \mathrm{mM}$ in phosphate buffer) was added directly ( $2.3 \%$ of total volume) to a $0.1 \mathrm{M}$ AOT/isooctane reverse micelle solution containing $0.5 \mathrm{mM}$ EPS with or without chloroperoxidase ( $2 \mu \mathrm{M}$ in $2.3 \%$ aqueous phase). Samples were incubated for 0.5 hour. All conditions were tested in duplicate; replicate aliquots were analyzed for EPSx. Error bars represent standard deviation. 
85\% conversion to EPSx (Figure 6); addition of peroxide initially in a reverse micelle solution (followed by direct peroxide addition) possibly enhanced conversion with the two highest peroxide concentrations tested (see two righthand most bars in Figure 6).

The extent of EPS sulfoxidation by chloroperoxidase in the reverse micelle solution was compared to that in aqueous solution, using the same total amount of enzyme and peroxide in the two systems. As indicated in: Figure 7, chloroperoxidase in reverse micelles, under conditions de'rribed in the above studies, generated nearly the same arrount of $1 \mathrm{~ms} \times$ in $20.5 \mathrm{hr}$ incubation as was observed in aqueous sclution. The varkbility in HISx levels among samples was higher when the extyme was tosed in roverse micelles.

In the experiments described above, despite whesmal conversion of EPS to EPSx, further oxidation of EPSx to EPSn was obsered. Astudy was conducted to test whether sequential addition of both arzyme are peroxide would enhance the stepwise oxidation of EPS to EPSn. Ali camiles were incubated for $1.5 \mathrm{hr}$. The same total amount of enzyme and peroxide was: added in making all samples. However, in "sequential" samples half the enzyme and peroxide was added $0.5 \mathrm{hr}$ after beginning the incubation. This approach increased the production of EPSx to nearly $90 \%$ of the substrate starting concentration (Figure 8). Replication of this experiment with analysis of EPSx levels from the two studies indicated significantly greater conversion with sequential addition of catalysts ( $p<0.001$, Students' $t$-test). However, concentrations of EPSn remained extremely low at about $7 \mu \mathrm{M}$ (Figure 8). Another metabolite with a retention time similar to EPSnwas consistently detecied in these experiments and appeared to be the unidentified material observed in previously reported studies. The production of this compound 


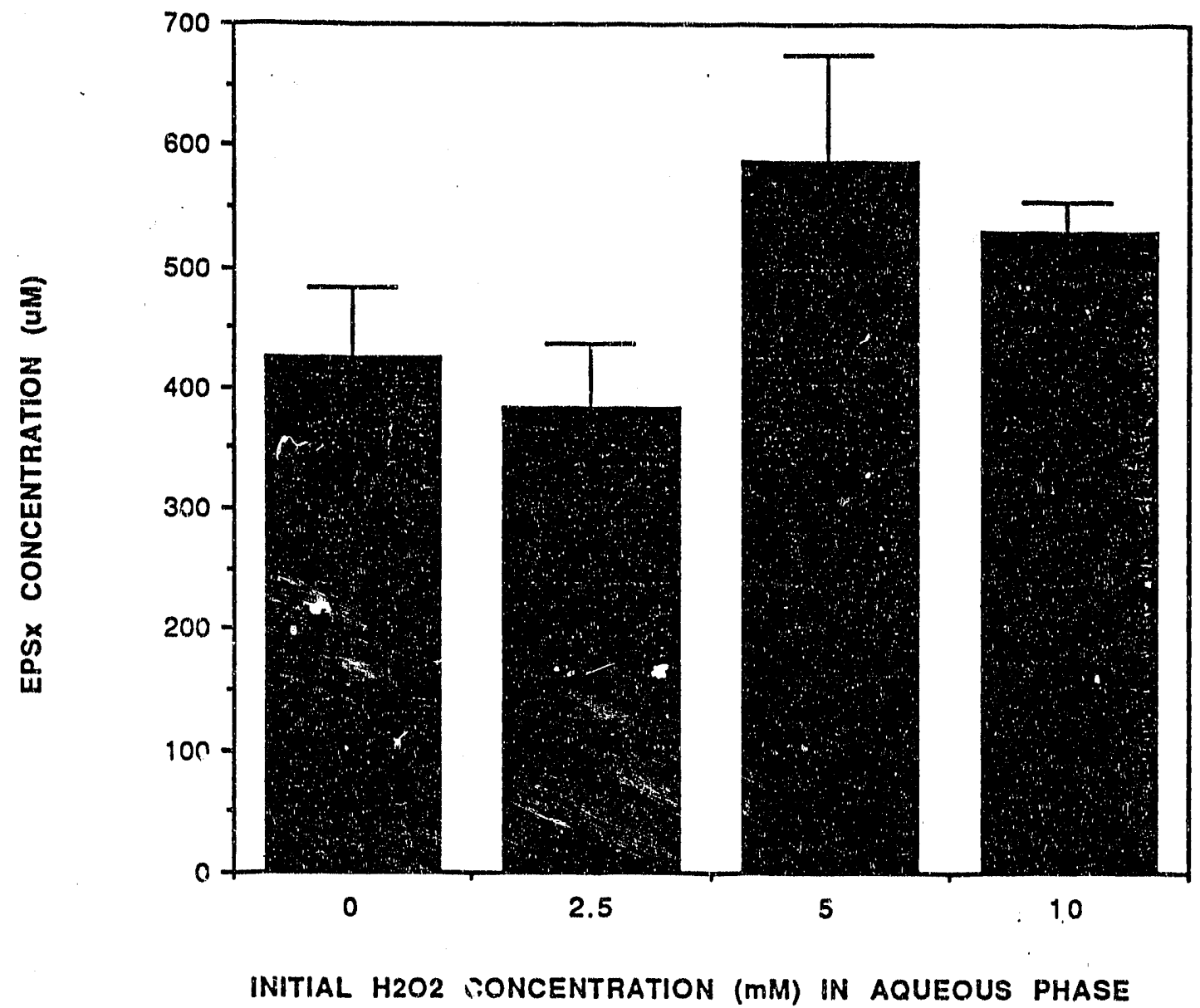

Fig. 6 Relationship of Initial $\mathrm{H}_{2} \mathrm{O}_{2}$ Concentration to EPS Sulfoxidation by Chloroperoxidase in Reverse Micelle Solution. Two 0.1M AOT/isooctane reverse micelle solutions with $0.5 \mathrm{mM}$ EPS, one containing chloroperoxidase $\left(2 \mu \mathrm{M}\right.$ in $1.15 \%$ aqueous phase) and the other $\mathrm{H}_{2} \mathrm{O}_{2}(0-20 \mathrm{mM}$ in $1.15 \%$ aqueous phase), were combined in equal volume. Within two minutes, $\mathrm{H}_{2} \mathrm{O}_{2}$ (20mM in phosphate buffer) was added directly to the combined reverse micelle solutions, $2.3 \%$ of total volume. After 0.5 hour, duplicate samples were analyzed for EPSx. Error bars represent standard deviation. 


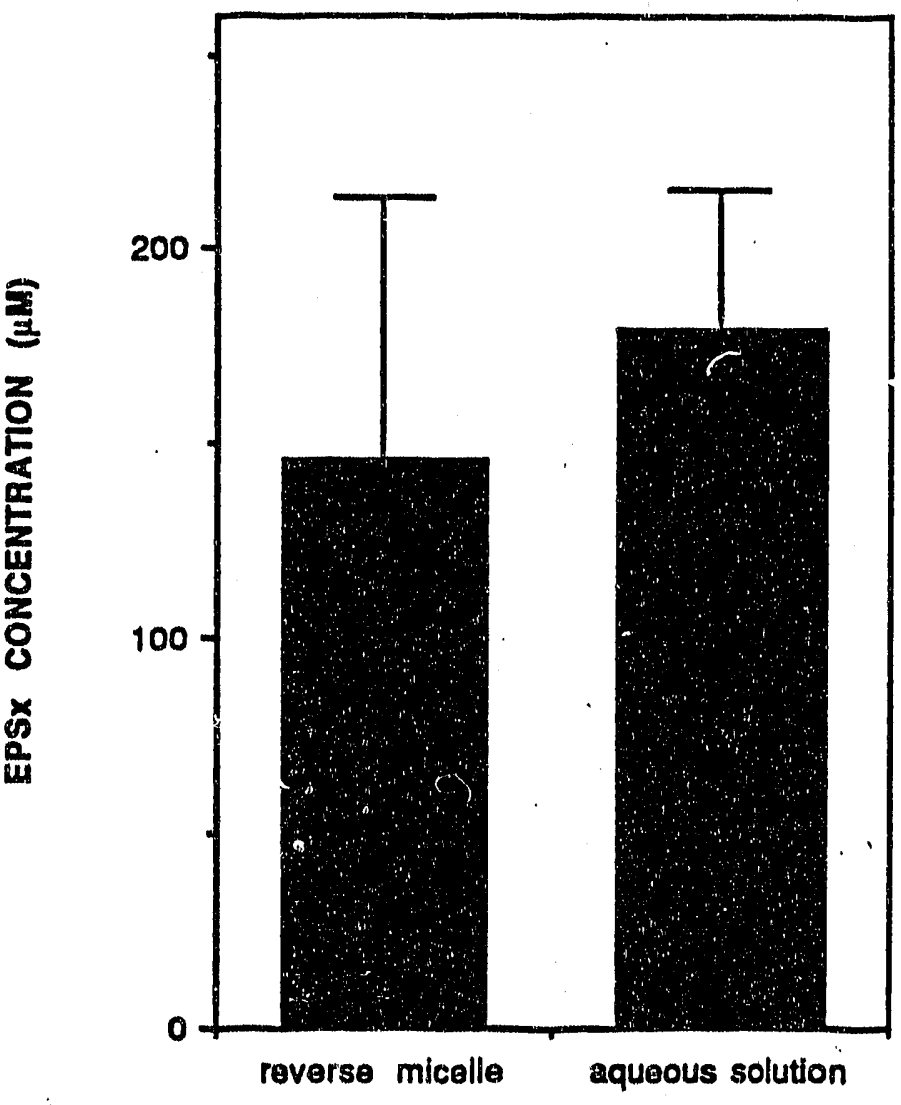

SAMPLE CONDITIONS

Fig. 7: Comparison of EPS Sulfoxidation by Choroperoxidase in Aqueous and Reverse Micelle Solutions. Reverse micelle solutions (1 $\mathrm{ml}$ in triplicate) consisted of $0.5 \mathrm{M}$ EPS in $0.1 \mathrm{M} \mathrm{AOT/isooctane}$ with chloroperoxidase $(2 \mu \mathrm{M}$ in $0.1 \mathrm{M}$ phosphate buffer, $2.3 \%$ of total volume) to which was added $\mathrm{H}_{2} \mathrm{O}_{2}(20$ $\mathrm{mM}$ in phosphate buffer, $2.3 \%$ of total volume). Aqueous solutions (1 $\mathrm{ml}$ in triplicate) were made by adding the same amount of enzyme and peroxide to phosphate buffer with $0.5 \mathrm{M}$ EPS. Solutions were incubated for $0.5 \mathrm{hr}$. Error bars represent standard deviation. 


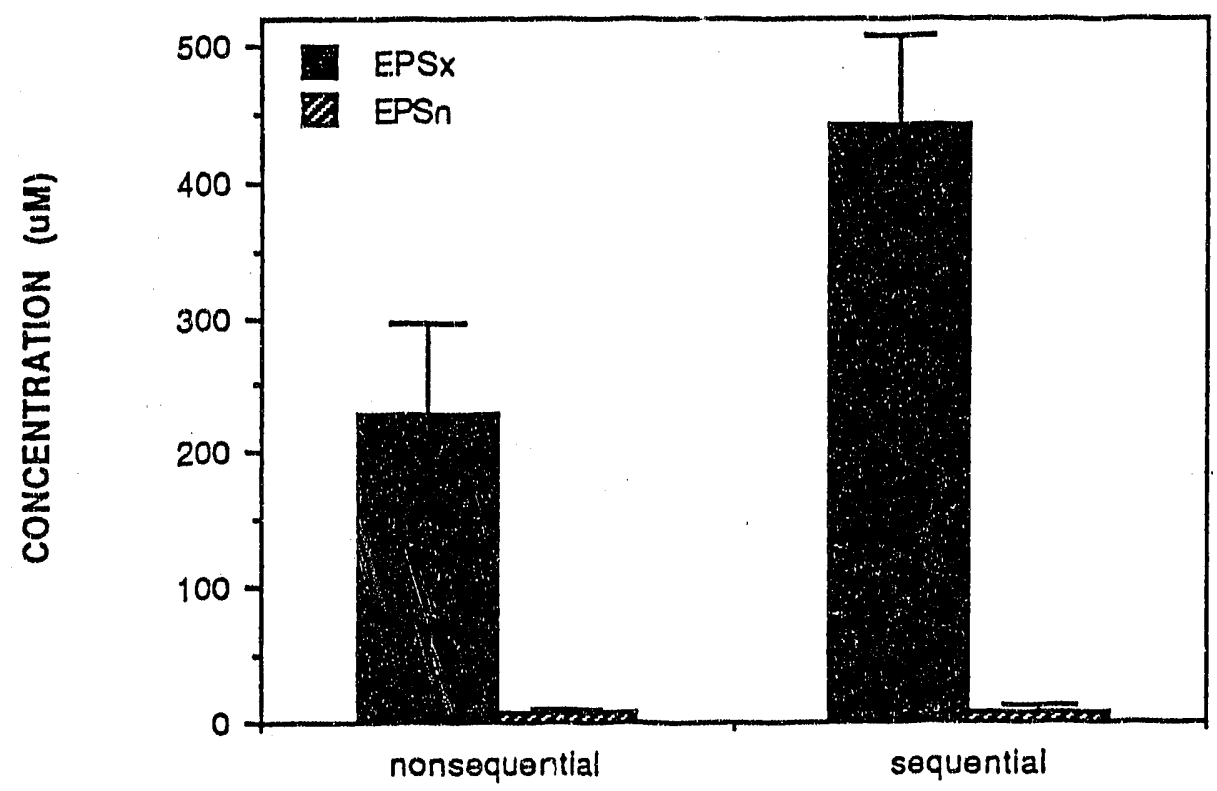

SAMPLE CONDITIONS

Fig. 8 : The Effect of Sequential Addition of Enzyme and $\mathrm{H}_{2} \mathrm{O}_{2}$ on Oxidation of EPS and EPSx in AOT/isooctane Reverse Micelle Solutions. Nonsequential samples were made by adding $2.3 \% \mathrm{KH}_{2} \mathrm{PO}_{4}$ buffer containing $2 \mu \mathrm{M}$ chloroperoxidase and $2.3 \% \mathrm{KH}_{2} \mathrm{PO}_{4}$ buffer containing $20 \mathrm{mM} \mathrm{H}_{2} \mathrm{O}_{2}$ to 0.5 $\mathrm{mM}$ EPS in AOT/isooctant, respectively. The samples were incubated for 1.5 hours at room temperature. Sequential samples were made by:1) adding $1.15 \% \mathrm{KH}_{2} \mathrm{PO}_{4}$ buffer containing $2 \mu \mathrm{M}$ chloroperoxidase and $1.15 \% \mathrm{KH}_{2} \mathrm{PO}_{4}$ buffer containing $20 \mathrm{mM} \mathrm{H}_{2} \mathrm{O}_{2}$ to $0.5 \mathrm{mM}$ EPS in AOT/isooctane, respectively, and incubating the samples for 0.5 hour; 2) after 0.5 hour of incubation, adding $1.15 \% \mathrm{KH}_{2} \mathrm{PO}_{4}$ buffer contaning $2 \mu \mathrm{M}$ enzyme and $1.15 \% \mathrm{KH}_{2} \mathrm{PO}_{4}$ buffer containing $20 \mathrm{mM} \mathrm{H}_{2} \mathrm{O}_{2}$ to the solutions again and then incubating the sample for another one hour at room temperature. Error bars represent standard deviation. 
appeared to be increased by sequential addition of enzyme and peroxide (Figure 9).

\subsection{EPSx Sulfoxidation by Chloroperoxidase in AOT/Isooctane Reverse Micelle Solutions}

The lack of conversion of EPS to EPSn could not be explained by inability of chloroperoxidase to catalyze oxidation of EPSx in reverse micelle solution. As previously shown in aqueous conditions, EPSx incubated in reverse micelles with chloroperoxidase was about $35 \%$ converted to EPSn (Figure 10). The peak area associated with the unidentified metabolite was about 20-fold higher than observed in the sequential study described above.

\subsection{Secondary Structure of Chloroperoxidase in Aqueous and Reverse Micelle Solutions}

The $C D$ spectra for chloroperoxidase in aqueous and reverse micelle solutions are presented separately in Figure 11 and then superimposed in Figure 12. Interpretation of the molar ellipticity indicates that in aqueous solution the enzyme structure consists of $32.6 \% \alpha$-helix, $0.6 \% \beta$-turn, $66.8 \%$ random and no $\beta$-sheet. In contrast, in the reverse micelle solution the structure is primarily in the $\beta$-sheet configuration (72.4\%), with $2.2 \% \beta$-turn and $25.4 \%$ random. The interpretation of the structure differs if the enzyme concentration is expressed relative to the total volume of the reverse micelle solution (ie. $2 \mu \mathrm{M}$ rather then $100 \mu \mathrm{M}$ ). Then the analysis suggests $12.1 \% \alpha-$ helix, $29.3 \% \beta$-turn, $58.6 \%$ random and no $\beta$-sheet. The interpretation is further complicated by the need to use a relatively high enzyme concentration $(100 \mu \mathrm{M})$ in the aqueous phase of the reverse micelle solution in order to obtain a spectrum. This concentration is considerably higher than that used in EPS studies and under these conditions the enzyme may aggregate within the reverse micelle or undergo other structural modifications. 


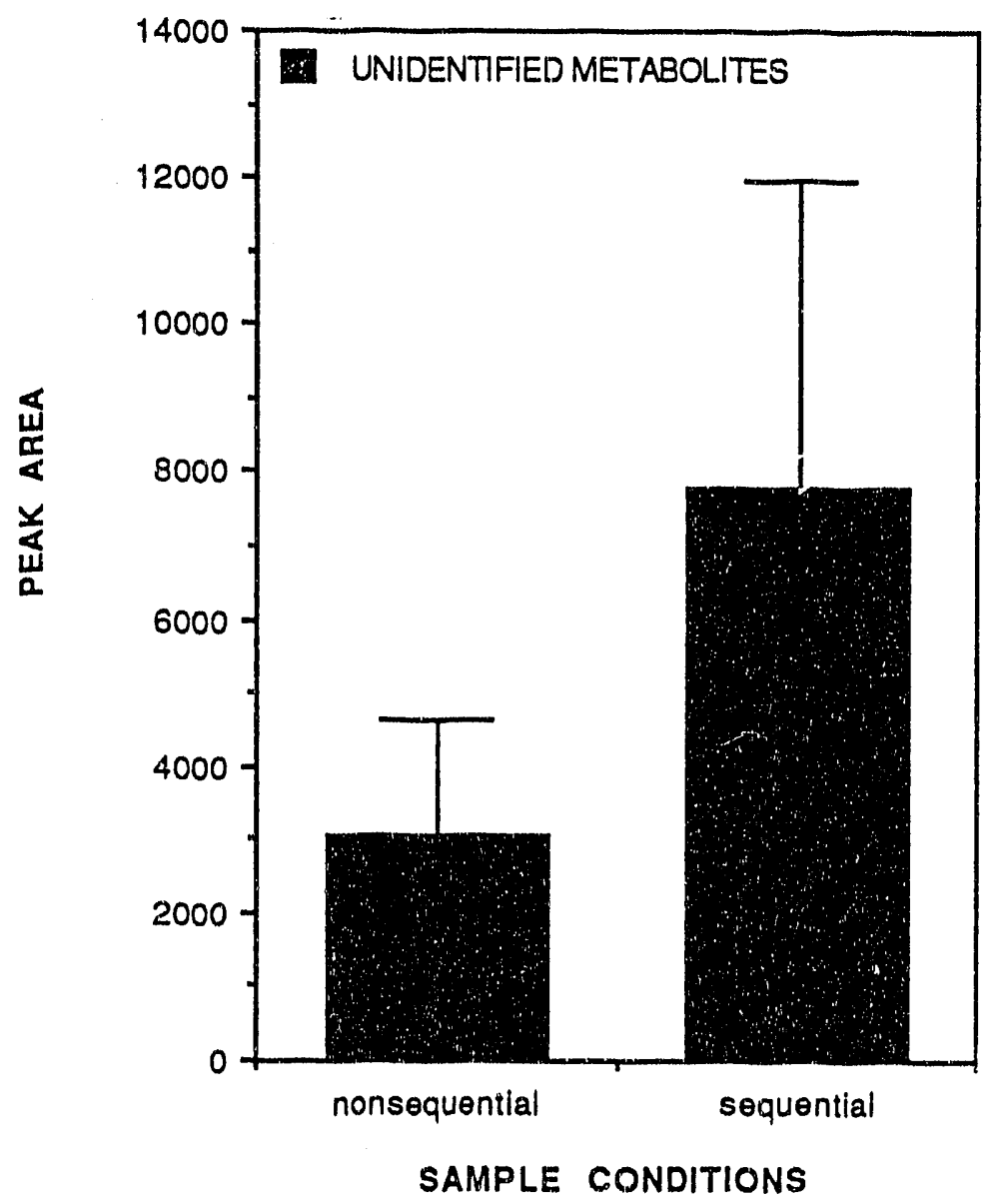

Fig. 9: The Effect of Sequential Addition of Enzyme and $\mathrm{H}_{2} \mathrm{O}_{2}$ on Oxidation of EPS to an Unidentified Material in AOT/isooctane Reverse Micelle Solutions. Nonsequential samples were made by adding $2.3 \%$ $\mathrm{KH}_{2} \mathrm{PO}_{4}$ buffer containing $2 \mu \mathrm{M}$ chloroperoxidase and $2.3 \% \mathrm{KH}_{2} \mathrm{PO}_{4}$ buffer containing $20 \mathrm{mM} \mathrm{H}_{2} \mathrm{O}_{2}$ to $0.5 \mathrm{mM}$ EPS in AOT/isooctane, respectively. The samples were incubated for 1.5 hours at room temperature. Sequential samples were made by : 1 ) adding $1.15 \% \mathrm{KH}_{2} \mathrm{PO}_{4}$ buffer containing $2 \mu \mathrm{M}$ chloroperoxidase and $1.15 \% \mathrm{KH}_{2} \mathrm{PO}_{4}$ buffer containing $20 \mathrm{mM} \mathrm{H}_{2} \mathrm{O}_{2}$ to $0.5 \mathrm{mM}$ EPS in AOT/isooctane, respectively, and incubating the samples for 0.5 hour; 2) after 0.5 hour of incubation, adding $1.15 \% \mathrm{KH}_{2} \mathrm{PO}_{4}$ buffer contaning $2 \mu \mathrm{M}$ enzyme and $1.15 \% \mathrm{KH}_{2} \mathrm{PO}_{4}$ buffer containing $20 \mathrm{mM} \mathrm{H} \mathrm{H}_{2} \mathrm{O}_{2}$ to the solutions again and then incubating the sample for another one hour at room temperature. Error bars represent standard deviation. 


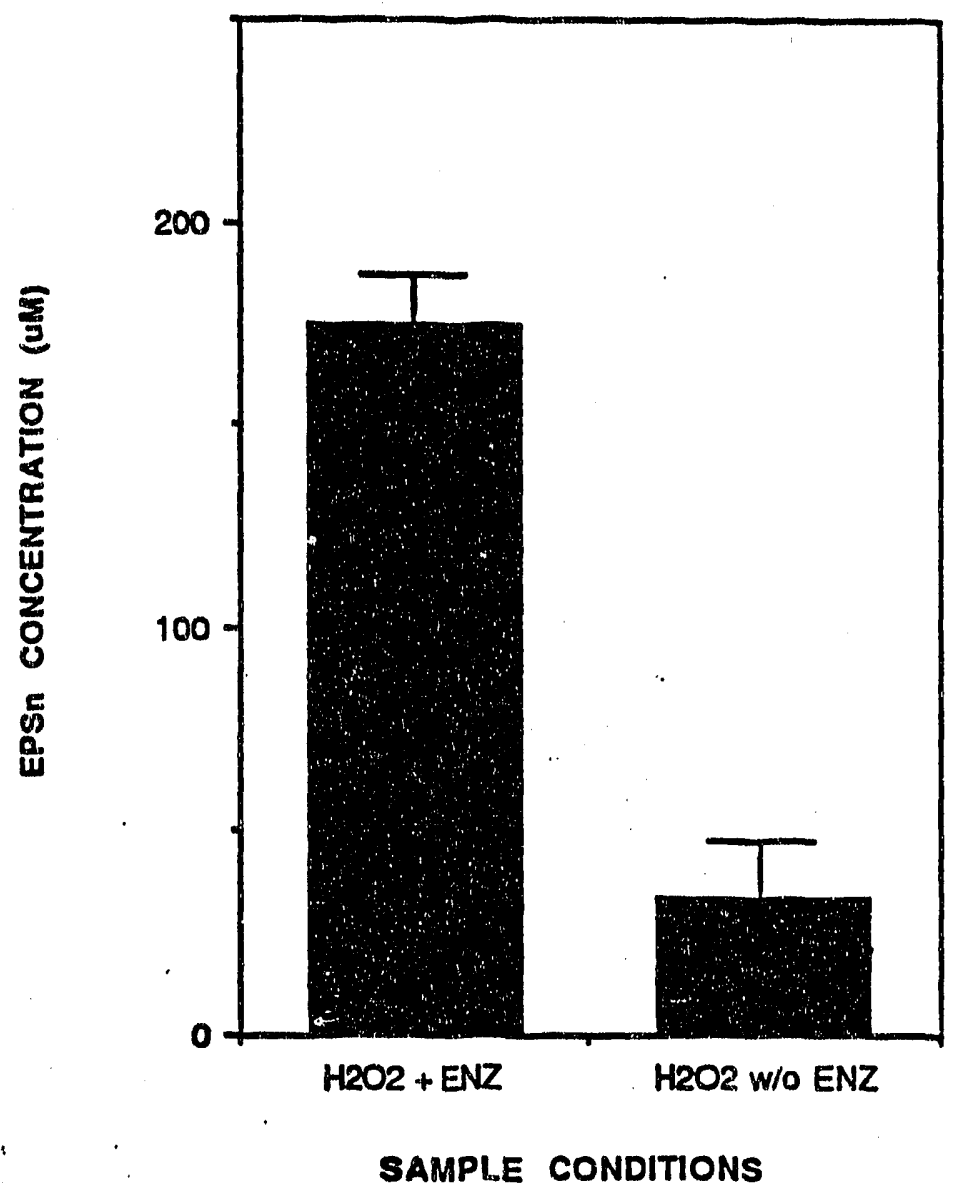

Fig. 10: EPSx Oxidation by Choroperoxidase in Reverse Micelle Solution. EPSx $(0.5 \mathrm{M})$ was incubated for $0.5 \mathrm{hr}$ in $0.1 \mathrm{M}$ AOT/isooctane to which was added $0.1 \mathrm{M}$ phosphate buffer $(2.3 \%$ of total volume) with or without chloroperoxidase $(2 \mu \mathrm{M})$ and $\mathrm{H}_{2} \mathrm{O}_{2}(20$ $\mathrm{mM}$ in phosphate buffer, $2.3 \%$ of total volume). Error bars represent standard deviation for replicate samples. 


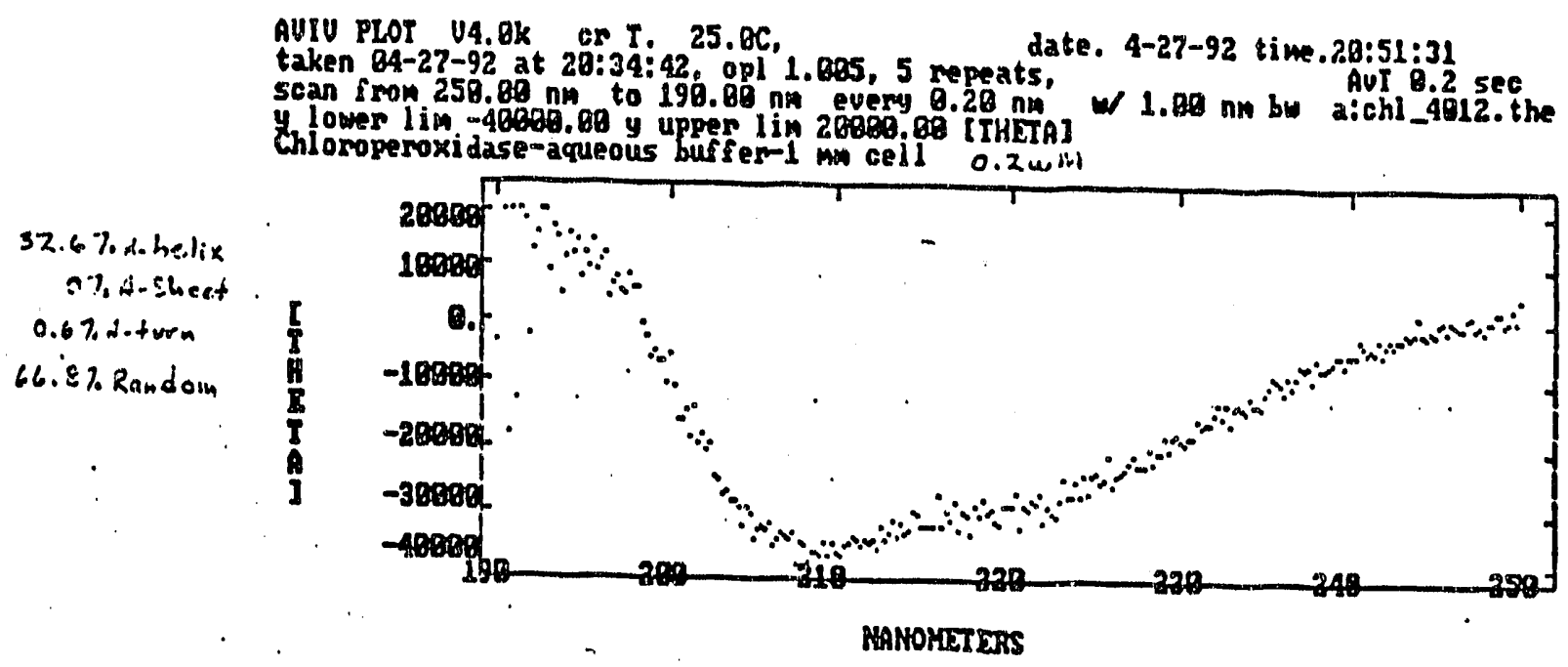

AUIV PLOT U4.8k ce T. 25.8C, date. 4-27-92 time.20:52:55 taken 84-27-92 at 20:22:33, opl 1.895, 18 repeats, 4-27-92 time.28:52:55

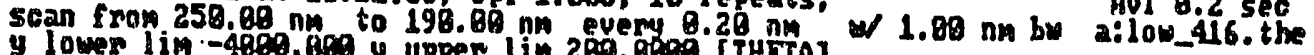

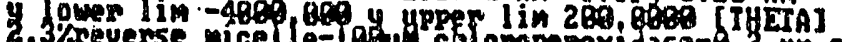

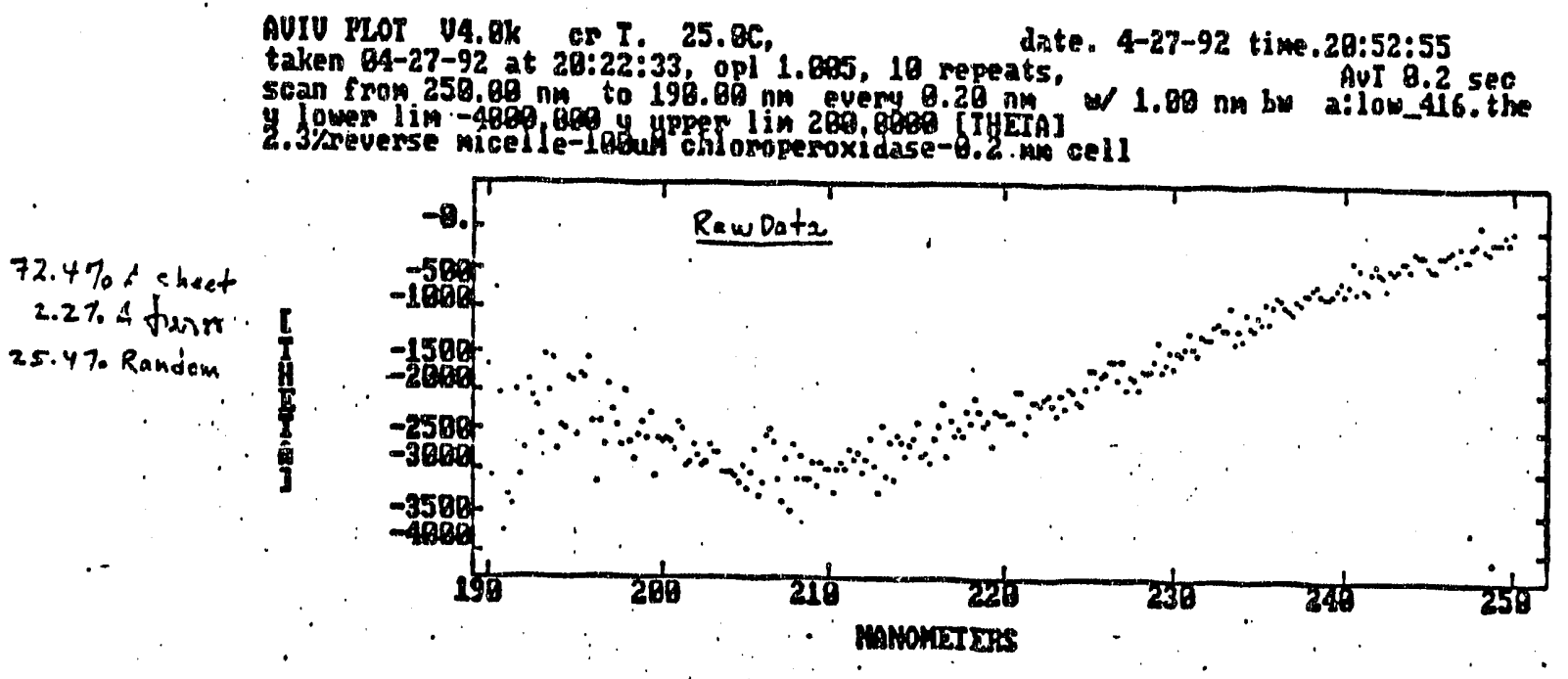
Fig. 11: CD Spectra of Chloroperoxidase in Aqueous (top) and Reverse
Micelle (bottom) Solutions 
AUIU PLOT U4, BK CK, T, 25. OC, date. 4-27-92 time.20:55:47 taken 04-27-92 at 20:34:42, opl 1.805, 5 repeats,

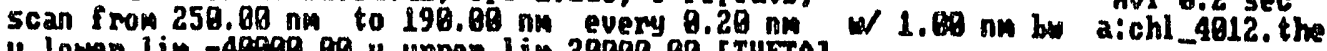

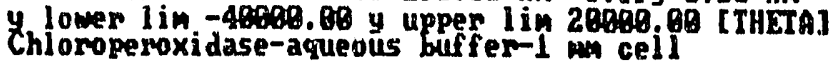

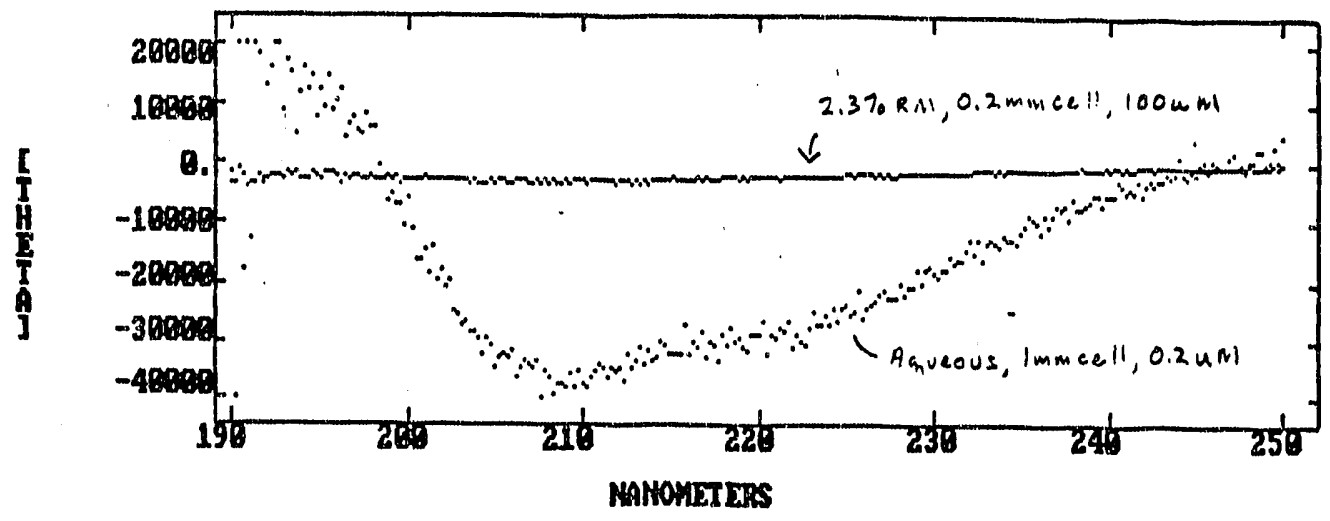

Fig. 12: Superimposed CD Spectra of Chloroperoxidase in Aqueous and Reverse Micelle Solutions 


\section{Section 4}

\section{PLANS FOR. THE ELEVENTH QUARTER}

1. Further study of chloroperoxidase and bacterial and mammalian enzymes (Holland, 1988, Kobayashi et al., 1986, and Rettie et al., 1990) for sulfur oxidizing activity.

2. Methodology for maximizing EPS sulfoxidation to EPSn by chloroperoxidase in reverse micelle solution.

3. Evaluation of DBT as substrate for chloroperoxidase in reverse micelle solutions.

4. Development of analytical assay for EPSx in a CTAB/1-hexanol reverse micelle solution and determination of EPS sulfoxidation by chloroperoxidase in this solution.

Section 5

\section{BIBLIOGRAPHY}

Fang, G.H., Kenigsberg, P., Axley, M.J., Nuell, M., and Hager, L.P. Cloning and sequencing of chloroperoxidase cDNA. Nucleic Acids Research 14 (20): 8061-8071, 1986.

Hager, L.P., Morris, D.R., Brown, F.S., and Eberwein, H.

Chloroperoxidase: utilization of halogen anions. Journal of Biological Chemistry 241: 1769-1777, 1966.

Holland, H.E. Chiral sulfoxidation by biotransformation of organic suifides. Chem. Rev. 88: 473-485, 1988.

Kabanov, A.V., Levashov, A.V., Klyachko, N.L., Namyotkin, S.N., Pshezhetsky, A.V. and Martinek, K. Enzymes entrapped in reversed micelles of surfactants in organic solvents: a theoretical treatment of the catalytic activity regulation. I. Theor. Biol. 133: 327-343, 1988. 
Kobayashi, S., Nakano, M., Goto,T., Kimura, T., and Schaap, A.P. Evidence of the peroxidase-dependent oxygen transfer from hydrogen peroxide to sulfides. Biochemical and Biophysical Research Communications 135: 166-171, 1986.

Light, D. R., Waxman, D. J., and Walsh, C. T. Studies on the chirality of sulfoxidation catalyzed by bacterial flavoenzyme cyclohexanone monooxygenase and hog liver flavin adenine dinucleotide containing monooxygenase. Biochemistry 21: 2490-2498, 1982.

Martinek, K. Micellar enzymology: potentialities in furdamental and applied areas. Biochemistry International 18: 871-893, 1989.

Martinek, K., Levashov, A.V., Klyachko, N.L., Pantin, V.I., and Berezin, I.V. The principles of enzyme stabilization vs. catalysis by water-soluble enzymes entrapped into reversed micelles of surfactants in organic solvents. Biochim. Biophys. Acta 657: 277-294, 1981.

Morris, D.R., and Lowell, L.P. Chloroperoxisase I. Isolation and properties of the crystalline glycoprotein. I. Biol. Chem. 241: 1763-1768, 1966.

Rettie, A.E., Bogucki, B.D., Lim, I., and Meier, G.P. Stereoselective sulfoxidation of a series of alkyl p-tolyl sulfides by microsomal and purified flavin-containing monooxygenases. Molecular Pharmacology 37: 643-651, 1990.

Verhaert, R.M.D., Hilhorst, R., Vermue, M., Schaafsma, J.J., and Veeger, C. Description of enzyme kinetics in reversed micelles. 1. Theory. Eur. I. Biochem. 187: 59-72, 1990.

Van Horne, K.C. Sorbent Extraction Technology. Analytichem International, Inc., 1990.

Waxman, D. J., Light, D. R., and Walsh, C. T. Chiral sulfoxidations catalyzed by rat liver cytochromes P-450. Biochemistry 21: 2499-2507, 1982. 

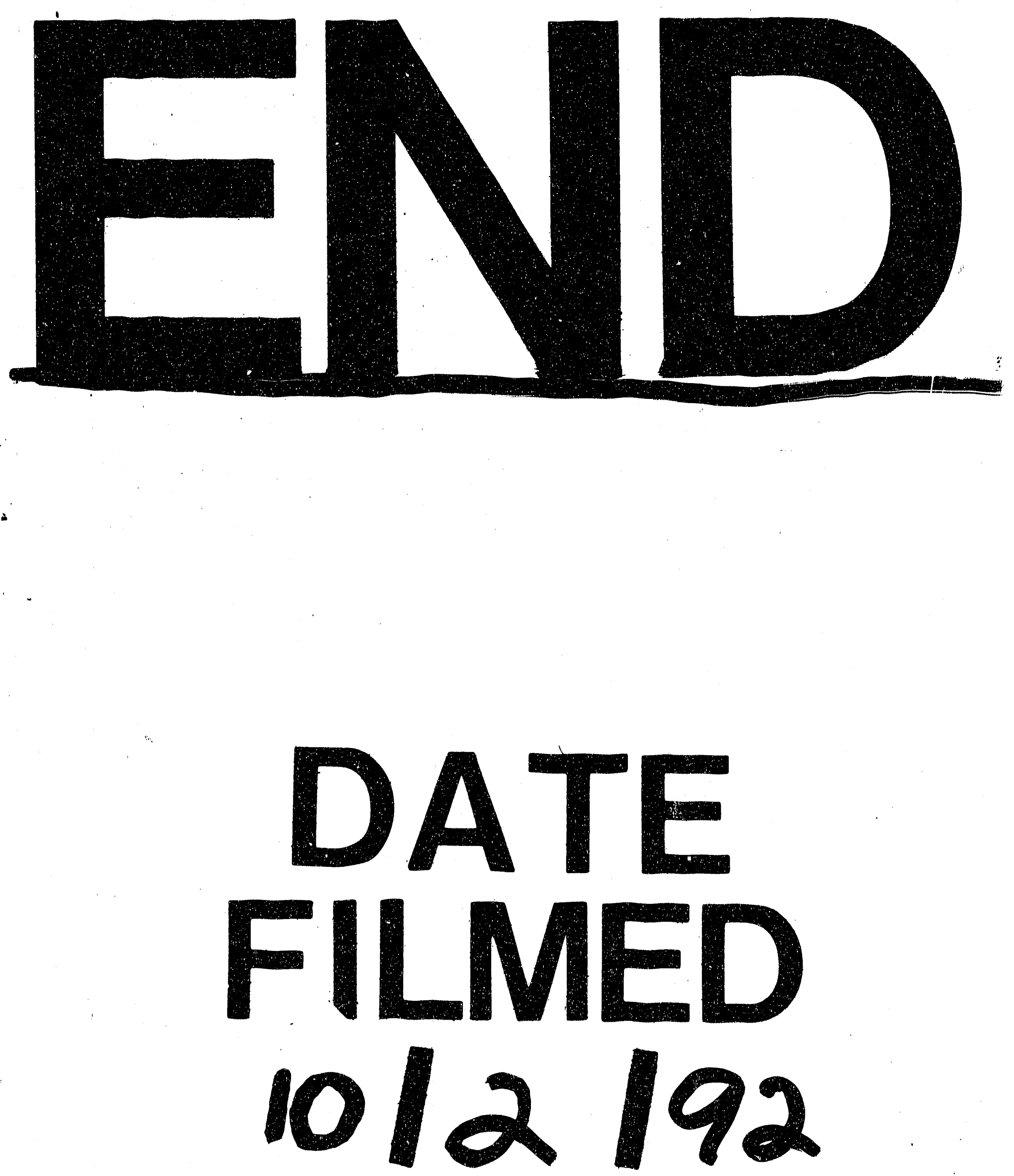
